\title{
ANALYSIS OF GENETIC DIVERSITY IN LINSEED USING AFLP MARKERS
}

\author{
Adugna Wakjira ${ }^{1}$, C.D. Viljoen ${ }^{2}$ and M.T. Labuschagne ${ }^{2}$ \\ 1 EARO, Holetta Agricultural Research Centre, PO Box 2003, Addis Ababa, Ethiopia \\ Email: AdugnaWG@yahoo.com \\ 2 Department of Plant Sciences (Plant Breeding), UFS, PO Box 339 \\ Bloemfontein 9300, Republic of South Africa
}

\begin{abstract}
Linseed (Linum usitatissimum L.) is the second most important oilseed crop in the highlands of Ethiopia where it has been cultivated for its valuable seed-oil since antiquity. Sixty accessions of linseed predominantly from Ethiopia were analysed using amplified fragment length polymorphism (AFLP) markers to assess their genetic diversity. Out of seven pairs of AFLP primers screened, Eco-ACA/ Mse-CAT and Eco-ACA/ Mse-CTT resulted in a greater number of amplification products. The estimated genetic distance for pairwise accessions significantly $(\mathrm{P}<0.001)$ varied from 0.29 to 0.71 , indicating the prevalence of genetic diversity in both exotic and local collections. Introductions from Canada and collections from different parts of Ethiopia, especially those from central and northwest regions revealed considerable variations between and within their geographic locations and thus can be used to create genetic variations. Cluster analysis categorized the 60 accessions into 13 classes, each consisting of one to 14 accessions. Two introduced accession were individually clustered, showing their greater divergence. AFLP analysis was found effective in discriminating the accessions and in selecting suitable parents for future genetic improvement. It was also useful for efficient management of genetic resources, eliminating unnecessary duplications.
\end{abstract}

\section{Key words/phrases: AFLP, DNA markers, genetic diversity, linseed}

\section{INTRODUCTION}

Linseed (Linum usitatissimum L.) is an important oilseed crop in the subtropics and temperate regions of the world (Luhs and Friedt, 1994). The extracted oils of linseed are mostly used for paints, varnish and other industrial uses. Recently, its potential as a highly nutritive source, rich in linolenic acid and lignan, both imparting multiple health benefits was well recognized (Payne, 2000; Morris, 2004). Linseed, after noug (Guizotia abyssinica Cass) is the second most important oilseed crop in the highlands of Ethiopia (Adugna Wakjira, 2000). In 2001, about 50, 000 tons were produced from 99,000 hectares (CSA, 2001). Existing varieties of linseed in Ethiopia have been developed for a number of traits including high seed set, oil content, variation in maturity period, increased adaptability to different growing environments, enhanced resistance to pathogens, pests and other biotic and abiotic stresses (Adugna Wakjira and Labuschagne, 2002). Breeding improved cultivars of linseed is generally based on selection from germplasm and crosses and selection is often based on the standard pedigree method (Adugna Wakjira, 2000). However, parental genotypes are often selected on the basis of phenotypic performance and this may not be sufficient to determine genetic constitution. This limits the likelihood of developing successful new varieties. Thus, DNA marker-assisted selection (MAS), which indicates the true genetic constitution, may help to overcome such problems.

Genetic diversity analysis of linseed germplasm can reveal the extent of genetic relatedness among accessions by estimating their genetic distance and is useful in the conservation of genetic resources. It is also important for cultivar identification and seed certification programs. Under the International Union for the Protection of New Varieties of Plants (UPOV, 1991), plant breeders' rights (PBR) are based on criteria of distinctiveness, uniformity and stability (DUS) of genotypes. In Ethiopia, linseed cultivars are currently distinguished from each other on the basis of a number of morphological characters (Adugna Wakjira and Labuschagne, 2004). However, expression of traits, such as days to flowering and maturity, plant height, number of branches and seed yield is significantly 
influenced by the environment (Adugna Wakjira and Labuschagne, 2002; 2003a; 2003b) and present problems for consistent identification. But molecular markers or DNA fingerprints are not affected by environmental factors, and provide a new means to support cultivar identification (Kumar, 1999). Such markers are accepted as supplementary characters for identification in many countries (Roldan-Ruiz et al., 2001), and are important for the assessment of DUS criteria and the establishment of PBR, which are essential in the derivation of new varieties and seed purity certification.

Amplified fragment length polymophism (AFLP), was initially developed by Zabeau and Vos (1993) and has proved an efficient polymerase chain reaction (PCR) based technique to generate a large number of polymorphic DNA fragments (Vos et al., 1995; Altaf Khan et al., 2002). AFLP fingerprints are highly reproducible and have been used as a tool for evaluating genetic diversity (Majer et al., 1996; Guthridge et al., 2001). AFLP markers are reproducible even against the background of different combinations of Taq DNA polymerases and buffers (Powell et al., 1996). However, the quantities of higher molecular weight fragments (< 400 base pairs, bp) are reduced when using plant DNA of poor quality (Guthridge et al., 2001).

An AFLP genetics of linseed was used to identify two quantitative trait loci in independent linkage groups that exhibit a major effect on resistance to Fusarium wilt, a deadly disease of linseed (Spielmeyer et al., 1998). This study illustrated the potential of AFLP as a powerful and fast method to generate moderately saturated linkage maps, allowing molecular analysis for traits that show oligogenic patterns of inheritance. Similarly, Hausner et al. (1998) developed co-dominant PCR/RFLP based markers for rust resistance alleles of linseed. These markers were used to confirm the presence of important alleles in certain recently released Canadian cultivars. This evidence adds to the growing support for the use of MAS and the introduction of new resistance genes for diseases like rust, Fusarium wilt and other important traits in the Ethiopian linseed-breeding program. Therefore, the aim of this study was to analyse and determine the genetic variation among the accessions of linseed using AFLP markers and thereby to enhance the genetic improvement of linseed in Ethiopia.

\section{MATERIALS AND METHODS}

The materials comprised of sixty accessions of linseed germplasm maintained under the Highland Oil Crops Research Program of Holeta Research Centre of the Ethiopian Agricultural Research Organization (EARO). Those accessions were selected to represent the diversity of linseed germplasm in Ethiopia. Most of these accessions were collected from different regions of Ethiopia and Eritrea, while few were introductions from Europe, USA and Canada, including four nationally released cultivars viz., Chilalo, CI-1525, CI-1652 and Belay 96 (Table 1).

DNA was extracted from 1.5 month-old plant tissues harvested from three random plants per accession (tips of stem including leaves) grown under glasshouse conditions at the University of Free State, South Africa following the modified monocot extraction protocol (Edwards et al., 1991). The tissue was kept on ice until it was crushed to a fine powder in a mortar and pestle after the addition of liquid nitrogen. Extraction buffer (10 ml) (1 M Tris-HCl pH 8.0, 0.25 M EDTA and 20\% SDS) preheated at $65^{\circ} \mathrm{C}$ was added to each powdered sample along with $1 \mathrm{ml}$ СТАВ (Cetyl triethyl ammonium bromide) buffer $(10 \% \mathrm{w} / \mathrm{v})$ and $2 \mathrm{ml} 5 \mathrm{M} \mathrm{NaCl}$. The samples were incubated at $65^{\circ} \mathrm{C}$ in a water bath for an hour, with agitation every 10 to 20 minutes. Chloroform-isoamyl alcohol $(24: 1 \mathrm{v} / \mathrm{v})(10 \mathrm{ml})$, was added and gently mixed, followed by centrifugation for 15 minutes at $10000 \mathrm{rpm}$ at room temperature. Chloroform extractions were repeated until the interface was visibly free of debris. DNA was precipitated by adding $100 \%$ cold ethanol in a 1:2 (v/v) and kept at $4^{\circ} \mathrm{C}$ overnight. The precipitated DNA was spooled with a sterile Pasteur-pippette and washed twice in approximately $1 \mathrm{ml}$ of $70 \%$ ethanol. DNA was dissolved in $250 \mathrm{ml}$ double distilled sterile water and stored at $4^{\circ} \mathrm{C}$. DNA concentration and purity was determined using a spectrophotometer at 260 $\mathrm{nm}$. The quality of genomic DNA was assessed by agrose electrophoresis on $200 \mathrm{ng}$ DNA $(0.5 \mathrm{~g}$ agarose, $50 \mathrm{ml} 0.5 \times$ TAE buffer $(40 \mathrm{mM}$ Tris acetate $1 \mathrm{mM}$ EDTA, pH 8.0), $0.5 \mu$ l Ethidium bromide) for approximately 45 minutes at 80 volts. The integrity and concentration of DNA was visualized and confirmed against the standard DNA (Marker III) under UV light. The DNA samples were diluted to a working concentration of $250 \mathrm{ng} / \mu \mathrm{l}$ and stored at $4^{\circ} \mathrm{C}$. 
Table 1. Summary of 60 linseed accessions, their collection areas, AFLP generated fragments and their polymorphism using four AFLP primers analysed at the University of Free State, South Africa, 2002.

\begin{tabular}{|c|c|c|c|c|c|c|c|c|c|c|}
\hline $\begin{array}{l}\text { Ser. } \\
\text { No. }\end{array}$ & $\begin{array}{c}\text { Accession } \\
\text { No. }\end{array}$ & Collection area & $\begin{array}{c}\text { M2 } \\
\text { Fam }\end{array}$ & $\begin{array}{r}\text { M2 } \\
\text { Ned }\end{array}$ & $\begin{array}{c}\text { M4 } \\
\text { Fam }\end{array}$ & $\begin{array}{c}\text { M4 } \\
\text { Ned }\end{array}$ & $\begin{array}{l}\text { Sum Poly } \\
\text {-morphic }\end{array}$ & $\begin{array}{l}\text { Sum Mono } \\
\text {-morphic }\end{array}$ & $\begin{array}{l}\text { Polymor- } \\
\text { phism (\%) }\end{array}$ & $\begin{array}{l}\text { Monomor- } \\
\text { phism (\%) }\end{array}$ \\
\hline$\overline{1}$ & $' 10002^{\prime}$ & Shewa/ Ambo & 16.00 & 4.00 & 63.00 & 43.00 & 126.00 & 33.00 & 1.30 & 0.34 \\
\hline 2 & $' 10005^{\prime}$ & Sidamo/ Bore & 80.00 & 15.00 & 61.00 & 29.00 & 185.00 & 51.00 & 1.91 & 0.53 \\
\hline 3 & '10007' & Kefa/ Omonada & 47.00 & 8.00 & 46.00 & 24.00 & 125.00 & 42.00 & 1.29 & 0.43 \\
\hline 4 & $' 10008$ ' & Gonder/ Fogera & 89.00 & 10.00 & 62.00 & 32.00 & 193.00 & 39.00 & 1.99 & 0.40 \\
\hline 5 & $' 10010^{\prime}$ & Hararghe/ Chiro & 14.00 & 6.00 & 50.00 & 24.00 & 94.00 & 27.00 & 0.97 & 0.28 \\
\hline 6 & '10022' & Wello/ Kalu & 69.00 & 17.00 & 55.00 & 29.00 & 170.00 & 39.00 & 1.75 & 0.40 \\
\hline 7 & $' 10026$ ' & Gojam/ Dambecha & 27.00 & 45.00 & 54.00 & 23.00 & 149.00 & 39.00 & 1.54 & 0.40 \\
\hline 8 & $' 10037^{\prime}$ & Sidamo/ Bore & 35.00 & 8.00 & 67.00 & 44.00 & 154.00 & 57.00 & 1.59 & 0.59 \\
\hline 9 & $' 10039 '$ & Eritrea/ Mendefera & 3.00 & 9.00 & 53.00 & 28.00 & 93.00 & 30.00 & 0.96 & 0.31 \\
\hline 10 & 'Chilalo' & Arsi/ n.a. & 6.00 & 6.00 & 60.00 & 40.00 & 112.00 & 29.00 & 1.15 & 0.30 \\
\hline 11 & $' 10041 '$ & Bale/ Adaba & 52.00 & 46.00 & 6.00 & 3.00 & 107.00 & 14.00 & 1.10 & 0.14 \\
\hline 12 & $' 10046{ }^{\prime}$ & Welega/ Bedele & 37.00 & 35.00 & 5.00 & 7.00 & 84.00 & 9.00 & 0.87 & 0.09 \\
\hline 13 & $' 10060$ ' & Gonder/ Chera & 37.00 & 42.00 & 62.00 & 27.00 & 168.00 & 60.00 & 1.73 & 0.62 \\
\hline 14 & '10061' & Gamo-Gofa/ M-Abay & 40.00 & 45.00 & 74.00 & 31.00 & 190.00 & 63.00 & 1.96 & 0.65 \\
\hline 15 & $' 10068$ ' & Gojam/ Bahir-Dar & 66.00 & 38.00 & 57.00 & 37.00 & 198.00 & 47.00 & 2.04 & 0.48 \\
\hline 16 & $' 10080^{\prime}$ & Hararghe/ Habru & 98.00 & 25.00 & 65.00 & 40.00 & 228.00 & 48.00 & 2.35 & 0.49 \\
\hline 17 & $' 10085 '$ & Hararghe/ Kuni & 52.00 & 53.00 & 62.00 & 27.00 & 194.00 & 21.00 & 2.00 & 0.22 \\
\hline 18 & $' 10104$ ' & Shewa/ Dendi & 52.00 & 48.00 & 78.00 & 34.00 & 212.00 & 38.00 & 2.18 & 0.39 \\
\hline 19 & $' 10109$ ' & Shewa/ Tach-Bet & 79.00 & 56.00 & 76.00 & 38.00 & 249.00 & 31.00 & 2.57 & 0.32 \\
\hline 20 & 'CI-1525' & Europe/ n.a. & 23.00 & 57.00 & 107.00 & 35.00 & 222.00 & 39.00 & 2.29 & 0.40 \\
\hline 21 & '10111' & Shewa/ n.a. & 35.00 & 59.00 & 42.00 & 3.00 & 139.00 & 3.00 & 1.43 & 0.03 \\
\hline 22 & $' 10118$ ' & Shewa/ Ambo & 81.00 & 53.00 & 88.00 & 35.00 & 257.00 & 59.00 & 2.65 & 0.61 \\
\hline 23 & $' 10119$ ' & Shewa/ Chelia & 83.00 & 27.00 & 71.00 & 47.00 & 228.00 & 37.00 & 2.35 & 0.38 \\
\hline 24 & $' 10120^{\prime}$ & Sidamo/ Adola & 85.00 & 20.00 & 89.00 & 41.00 & 235.00 & 55.00 & 2.42 & 0.57 \\
\hline 25 & $' 10125$ ' & Tigray/ Inderta & 67.00 & 38.00 & 74.00 & 44.00 & 223.00 & 24.00 & 2.30 & 0.25 \\
\hline 26 & $' 10138 '$ & Welega/Abe-Dongoro & 69.00 & 14.00 & 58.00 & 23.00 & 164.00 & 29.00 & 1.69 & 0.30 \\
\hline 27 & $' 10144$ ' & Wello/ Dese-Zuria & 91.00 & 52.00 & 62.00 & 21.00 & 226.00 & 21.00 & 2.33 & 0.22 \\
\hline 28 & $' 10159$ ' & Gonder/ Dabat & 38.00 & 41.00 & 61.00 & 25.00 & 165.00 & 13.00 & 1.70 & 0.13 \\
\hline 29 & '10162' & Gonder/Dabat & 90.00 & 15.00 & 57.00 & 32.00 & 194.00 & 17.00 & 2.00 & 0.18 \\
\hline 30 & 'CI-1652' & Europe/ n.a. & 70.00 & 47.00 & 54.00 & 24.00 & 195.00 & 18.00 & 2.01 & 0.19 \\
\hline 31 & $' 10169 '$ & Gonder/ Chera & 67.00 & 58.00 & 64.00 & 36.00 & 225.00 & 18.00 & 2.32 & 0.19 \\
\hline 32 & '10176' & Gojam/ Guangua & 14.00 & 73.00 & 87.00 & 16.00 & 190.00 & 18.00 & 1.96 & 0.19 \\
\hline 33 & $' 10179 '$ & Shewa/ Alem-Gena & 6.00 & 5.00 & 7.00 & 4.00 & 22.00 & 0.00 & 0.23 & 0.00 \\
\hline 34 & '10185' & Shewa/ Chelia & 35.00 & 50.00 & 55.00 & 6.00 & 146.00 & 13.00 & 1.50 & 0.13 \\
\hline 35 & '10192' & Shewa/ Dendi & 64.00 & 46.00 & 42.00 & 22.00 & 174.00 & 7.00 & 1.79 & 0.07 \\
\hline 36 & '10197' & Shewa/ Ambo & 14.00 & 30.00 & 47.00 & 23.00 & 114.00 & 6.00 & 1.17 & 0.06 \\
\hline 37 & $' 10204$ ' & Welo/ Bati & 45.00 & 54.00 & 82.00 & 46.00 & 227.00 & 34.00 & 2.34 & 0.35 \\
\hline 38 & $' 10006$ ' & Ilubabor/ Gore & 70.00 & 51.00 & 61.00 & 41.00 & 223.00 & 15.00 & 2.30 & 0.15 \\
\hline 39 & $' 10042$ ' & Tigray/ Lay-Machew & 77.00 & 60.00 & 60.00 & 26.00 & 223.00 & 28.00 & 2.30 & 0.29 \\
\hline 40 & 'Belay 96' & Shewa/ Holeta & 66.00 & 52.00 & 64.00 & 41.00 & 223.00 & 21.00 & 2.30 & 0.22 \\
\hline 41 & $' 10047^{\prime}$ & Ilubabor/ Bedele & 75.00 & 37.00 & 45.00 & 16.00 & 173.00 & 15.00 & 1.78 & 0.15 \\
\hline 42 & $' 10062$ ' & Bale/ Robe & 37.00 & 16.00 & 49.00 & 43.00 & 145.00 & 22.00 & 1.49 & 0.23 \\
\hline 43 & $' 10235^{\prime}$ & Gonder/ n.a. & 63.00 & 49.00 & 69.00 & 14.00 & 195.00 & 28.00 & 2.01 & 0.29 \\
\hline 44 & '10236' & Gonder/ n.a. & 32.00 & 54.00 & 69.00 & 27.00 & 182.00 & 21.00 & 1.88 & 0.22 \\
\hline 45 & $' 10064$ ' & GamoGofa/BakoGazer & 87.00 & 52.00 & 83.00 & 43.00 & 265.00 & 21.00 & 2.73 & 0.22 \\
\hline 46 & $' 10072$ ' & Gojam/ Dejen & 82.00 & 57.00 & 48.00 & 29.00 & 216.00 & 9.00 & 2.23 & 0.09 \\
\hline 47 & $' 10073$ ' & Gojam/ Maychekel & 77.00 & 55.00 & 50.00 & 45.00 & 227.00 & 12.00 & 2.34 & 0.12 \\
\hline 48 & $' 10246$ ' & Ethiopia/ n.a. & 30.00 & 38.00 & 52.00 & 30.00 & 150.00 & 10.00 & 1.55 & 0.10 \\
\hline 49 & '10248' & Ethiopia/ n.a. & 18.00 & 26.00 & 53.00 & 30.00 & 127.00 & 37.00 & 1.31 & 0.38 \\
\hline 50 & $' 10250$ ' & Ethiopia/ n.a. & 21.00 & 42.00 & 48.00 & 48.00 & 159.00 & 14.00 & 1.64 & 0.14 \\
\hline 51 & $' 10252$ ' & Ethiopia/ n.a. & 13.00 & 9.00 & 9.00 & 6.00 & 37.00 & 2.00 & 0.38 & 0.02 \\
\hline 52 & $' 10254$ ' & Ethiopia/ n.a. & 16.00 & 31.00 & 87.00 & 31.00 & 165.00 & 39.00 & 1.70 & 0.40 \\
\hline 53 & $' 10256$ ' & Ethiopia/ n.a. & 17.00 & 36.00 & 62.00 & 25.00 & 140.00 & 16.00 & 1.44 & 0.16 \\
\hline 54 & '10258' & Ethiopia/ n.a. & 5.00 & 36.00 & 75.00 & 23.00 & 139.00 & 9.00 & 1.43 & 0.09 \\
\hline 55 & $' 10260$ ' & Ethiopia/ n.a. & 13.00 & 21.00 & 86.00 & 18.00 & 138.00 & 21.00 & 1.42 & 0.22 \\
\hline 56 & 'Omega' & USA / North Dakota & 10.00 & 23.00 & 61.00 & 11.00 & 105.00 & 22.00 & 1.08 & 0.23 \\
\hline 57 & 'R12-N1266' & Canada/ Saskatoon & 85.00 & 64.00 & 55.00 & 18.00 & 222.00 & 45.00 & 2.29 & 0.46 \\
\hline 58 & 'R12-M20G' & Canada/ Saskatoon & 72.00 & 57.00 & 35.00 & 10.00 & 174.00 & 40.00 & 1.79 & 0.41 \\
\hline 59 & 'CDC-1747' & Canada/ Saskatoon & 88.00 & 65.00 & 110.00 & 18.00 & 281.00 & 11.00 & 2.90 & 0.11 \\
\hline 60 & \multicolumn{2}{|c|}{ 'CDC-1747VG' Canada/ Saskatoon } & 9.00 & 8.00 & 49.00 & 25.00 & 91.00 & 9.00 & 0.94 & 0.09 \\
\hline & \multicolumn{2}{|l|}{ Sum } & 2542 & 1738 & 2801 & 1368 & 8449 & 1257.00 & 87.05 & 12.95 \\
\hline & \multicolumn{2}{|l|}{ Mean } & 42.37 & 28.97 & 46.68 & 22.80 & 140.82 & 20.95 & 1.45 & 0.22 \\
\hline & \multicolumn{2}{|c|}{ Polymorphic (\%) } & 26.19 & 17.91 & 28.86 & 14.09 & 87.05 & 12.95 & - & - \\
\hline & \multicolumn{2}{|l|}{$\operatorname{SE}( \pm)$} & 47.52 & 35.45 & 57.82 & 26.82 & 167.42 & - & - & - \\
\hline & \multicolumn{2}{|l|}{$\mathrm{CV}(\%)$} & 3.85 & 3.85 & 3.84 & 3.85 & 3.84 & - & - & - \\
\hline
\end{tabular}


RNase digestion was performed on each sample by the addition of $1 \mu \mathrm{l}(\mathrm{ng} / \mu \mathrm{l})$ RNase and incubated at $42^{\circ} \mathrm{C}$ for 30 minutes. Single genomic DNA digests were carried out to confirm the purity of DNA at $37^{\circ} \mathrm{C}$ for 30 minutes, as follows: $0.2 \mu \mathrm{l}$ EcoRI (units),

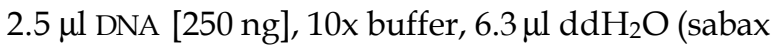
water), and $0.5 \mu \mathrm{l}$ MseI (units), $2.5 \mu \mathrm{l}$ DNA [250 ng], $1 \mu \mathrm{l} 10 \mathrm{x}$ buffer, $0.1 \mu \mathrm{l}$ BSA, $5.9 \mu \mathrm{l} \mathrm{ddH}_{2} \mathrm{O}$. After mixing, the DNA samples were incubated for 3 to 4 hours at $37^{\circ} \mathrm{C}$. Double digests were conducted by adding $2 \mu \mathrm{l}$ EcoRI/ MseI (units), $2.5 \mu \mathrm{l}$ DNA [250

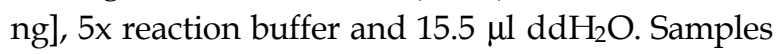
were incubated for two hours at $37^{\circ} \mathrm{C}$, after which the restriction enzymes were added for incubation at $70^{\circ} \mathrm{C}$ for 10 minutes. Ligation of EcoRI and MseI adapters was performed by mixing $25 \mu \mathrm{l}$ of double digested DNA, $24 \mu \mathrm{l}$ ligation solution (EcoRI/ MseI adapters, $0.4 \mathrm{mM}$ ATP, $10 \mathrm{mM}$ Tris- $\mathrm{HCl}$ ( $\mathrm{pH}$ 7.5) 10 $\mathrm{mM}$ Mg-acetate, $50 \mathrm{mM}$ K-acetate) and $1 \mu \mathrm{l}$ T4 DNA ligase (units). After incubation at $20^{\circ} \mathrm{C}$ for two hours, the ligated DNA was diluted 1:10 in TE buffer (10 mM Tris-HCl (pH 8.0) 0.1 mM EDTA).

The adapter-ligated DNA was pre-amplified using the following cycling parameters: 20 cycles of 30 seconds (s) at $94^{\circ} \mathrm{C}, 60 \mathrm{~s}$ at $56^{\circ} \mathrm{C}$, and $60 \mathrm{~s}$ at $72^{\circ} \mathrm{C}$. Amplification was confirmed by running 12 $\mu \mathrm{l}$ on a $1 \%$ agarose gel. Amplified DNA was diluted in a ratio of 1:50 and used as a template for the selective amplification involving EcoRI and MseI primers. Selective amplification was performed in a $20 \mu \mathrm{l}$ PCR reactions containing $5 \mu 1$ diluted preamplified DNA, $5.5 \mu \mathrm{l}$ Mix 1 (4.5 $\mu \mathrm{l}$ Msel primer (6.7 $\mathrm{ng} / \mu \mathrm{l}, \mathrm{dNTP}$ 's) and $1 \mu \mathrm{l}$ EcoRI Fam and Ned labelled primer) $(250 \mu \mathrm{l})$ and $9.5 \mu \mathrm{l}$ Mix $2(2 \mu \mathrm{l} 10 \mathrm{x}$ PCR buffer, $0.1 \mu \mathrm{l}$ Taq DNA polymerase (units), 7.4 $\mu 1$ sterile $\mathrm{dd} \mathrm{H}_{2} \mathrm{O}$ ). The cycling parameters were: 1 cycle of $30 \mathrm{~s}$ at $94^{\circ} \mathrm{C}, 30 \mathrm{~s}$ at $65^{\circ} \mathrm{C}$ and $120 \mathrm{~s}$ at $72^{\circ} \mathrm{C}$.
Thereafter, the annealing temperature lowered by $0.7^{\circ} \mathrm{C}$ per cycle for 12 consecutive cycles and then 23 cycles were performed at $94^{\circ} \mathrm{C}$ for $30 \mathrm{~s}, 56^{\circ} \mathrm{C}$ for $30 \mathrm{~s}$, and $72^{\circ} \mathrm{C}$ for $120 \mathrm{~s}$. The PCR product was prepared for capillary electrophoresis by the addition of $5 \mu \mathrm{l}$ Fam labelled PCR product, $5 \mu 1 \mathrm{Ned}$ labelled PCR product, $24 \mu \mathrm{l}$ deionised Formamide and $1 \mu 1$ Rox standard (cs-500) denatured at $94^{\circ} \mathrm{C}$ for 5 minutes with quick cooling in ice slurry. Capillary electrophoresis was performed using a Perkin Elmer Prism 310 Automated capillary sequencer $(\mathrm{PE}, 2002)$. A total of seven pairs of primer combinations were screened and four primers were selected based on the availability of primers and number of fragments amplified per primer pairs (Table 2). EcoRI primers (EE, 2002) labelled with Ned and Fam. Each accession was analysed with these primers and the primer extensions were Eco-ACA/ Mse-CAT and Eco-ACA/ Mse-CTT. The size of AFLP fragments was assessed by using GeneScan ${ }^{\circledR}$ Analysis Software (PE, 2002) and bands were scored for presence (1) or absence (0) across sixty accessions for each primer combination. Overlapping and non-overlapping fragments were separately counted, added and computed to sort out monomorphism and polymorphism rates. Euclidean genetic distances were calculated using the Number Cruncher Statistical System, NCSS 2000 (Hintze, 1998). Cluster analysis was also performed and visualized to summarize the relations between accessions. UPGMA (Unweighted pair group method of arithmetic average) was employed to construct a dendrogram that grouped the accessions into distinct clusters.

Table 2. List of adapters and primer pairs tested in this study for selective reaction in AFLP amplification.

\begin{tabular}{|c|c|c|c|}
\hline \multicolumn{2}{|c|}{ 5'-GACGATGAGTCCTGAG3' } & $\begin{array}{l}5 ' \text {-CTCC } \\
3^{\prime}-\text {-CATC }\end{array}$ & $\begin{array}{l}\text { dapter } \\
\text { 'TGCGTACC-3' } \\
\text { CATGGTTAA-5' }\end{array}$ \\
\hline Code & MseI - primer & EcoRI - primers & \\
\hline M2 & MseI + CAT & EcoRI + ACA (Fam) & $E c o \mathrm{RI}+\mathrm{ACC}(\mathrm{Ned})$ \\
\hline M3 & MseI + CTG & Eco RI + ACA (Fam) & $E c o \mathrm{RI}+\mathrm{ACC}(\mathrm{Ned})$ \\
\hline M4 & MseI + CTT & Eco RI + ACA (Fam) & $E c o R I+A C C(\mathrm{Ned})$ \\
\hline M5 & MseI + CTA & EcoRI + ACA (Fam) & $E c o \mathrm{RI}+\mathrm{ACC}(\mathrm{Ned})$ \\
\hline M6 & $M s e I+C A G$ & EcoRI + ACA (Fam) & Eco RI + ACC (Ned) \\
\hline M7 & MseI + CAC & Eco RI + ACA (Fam) & $E c o R I+A C C(\mathrm{Ned})$ \\
\hline M8 & MseI + CTC & EcoRI + ACA (Fam) & EcoRI + ACC (Ned) \\
\hline
\end{tabular}




\section{RESULTS AND DISCUSSION}

Of the seven pairs of primers screened (Table 2), Eco-ACA / Mse-CAT and Eco-ACA / Mse-CTT resulted in a greater number of amplification products. Primers Eco-ACA / Mse-CTG, Eco-ACA / Mse-CTA and Eco-ACA/ Mse-CAG also produced reasonable amplification, unlike Eco-ACA/ Mse-CAC and EcoACA/ Mse-CTC that resulted in poor amplification. Totally 9706 fragments (8449 polymorphic and 1257 monomophic bands) were generated by the two AFLP primer pairs for all the accessions (Table 1). Out the total AFLP bands, 0.23 to $2.90 \%$ polymorphism rates were detected for all accessions. The highest polymorphic rate was recorded for no. 59, an introduced accession from Canada. Three local accessions (no. 45, 22 and 19) also showed relatively higher polymorphism rates. The smallest $(0.23 \%)$ polymorphism rate was registered for no. 33, another local accession. These results suggest the presence of broad genetic diversity or prevalence variability in DNA sequences among the tested accessions. Of the four primer combinations, M4 Fam produced the highest $(28.86 \%)$, followed by that M2 Fam (26.19\%) polymorphism rates. In general, Fam labelled primers gave relatively higher polymorphism than the Ned labelled ones in this study.

For the primer combination Eco-ACA/ Mse-CAT, approximately 71 bands were scored ranging from 40 to $409 \mathrm{bp}$, whereas for the primer combination Eco-ACA/ Mse-CTT, 70 fragments were scored between 40 and $408 \mathrm{bp}$. Fam labelled Eco-ACA/ Mse-CTT primer generated an average of 47 AFLP fragments per accessions, followed by another Fam labelled Eco-ACA/ Mse-CAT, with 42 fragments. Two accessions (33 and 51) revealed considerably lower numbers of fragments. Both accessions were collected from Ethiopia (33 was specifically from central Shewa, while that 51 could not be traced back due to unavailability of data). These two accessions were also grouped under the same cluster in another diversity study of linseed that used morphological traits (Adugna Wakjira and Labuschagne, 2004), confirming their genetical similarity. However, there was no complete sharing of the AFLP fragments for any two accessions and monomorphism was in the range of zero to $0.65 \%$. Only six accessions displayed relatively higher (i.e., > 0.50\%) monomorphic rates. This indicates the presence of more genotypic variations among the evaluated accessions.

The dendrogram obtained from the combined data of AFLP revealed 13 close-knit clusters, comprising one to 14 accessions (Table 3 and Fig. 1). Two accessions showed greater dissimilarity with other accessions and hence were unequivocally clustered individually (XII and XIII) from the rest accessions, showing their clear divergence. The dendrogram also reveals some interesting features of the studied accessions. For example, each of the eight clusters (II to XI) was consisted of similar accessions originally collected from the same or closer localities of Ethiopia, indicating their closer relationships. Specifically, four accessions (No. 52, 53, 54, and 55) in cluster II, each two accessions in clusters III and IV (No. 13 and 28) and other accessions collected from the same geographic region were grouped within the same clusters and they are much similar to each other. Such similarity of accessions could happen due mainly to the traditional farmer-to-farmer seed exchange and distribution systems in Ethiopia. This shows how AFLP could play effective role in germplasm characterization for more efficient use of valuable genetic resources and other vital resources deployed to evaluate and conserve genetic resources by way of establishing core collections.

Accessions that were originally from central Ethiopia (Shewa) were categorized under six different clusters (V, VI, VII, XIII, IX and XI). Likewise, accessions collected from northwest Ethiopia (Gonder, for example) were classified into five clusters (IV, VI, VII, IX and XI). The same was true with most of the other local accessions. This indicates the presence of ample genetic variability among the Ethiopian linseed accessions that could be utilized in future breeding activities. On the other hand, some of the exotic accessions, like no. 30, 56 and 60, which were introduced from Europe, USA and Canada, respectively, were grouped in three different clusters (II, VI and VIII) together 
with the Ethiopian collections. This similarity could be as the result of out-crossing (Mansby et al., 2000), and perhaps due to trade and germplasm exchange programs that have been underway since long time between Ethiopia and other foreign nations. The results of this study show that clustering was not necessarily based on the geographic origins of the accessions, rather on genetic makeup of the accessions. The presence of a wide range of genetic variation between the accessions is a good basis for future genetic improvement. It could provide predictive estimates of genetic variation among segregating progenies in future variety development programs. Such a study can also help in estimating the amount of heterosis (Barret and Kidwell, 1998). Thus, knowledge of the level and patterns in genetic diversity of linseed was found useful for identifying diverse parental combinations to create segregating progenies with maximum genetic variability for subsequent selections, and to reduce duplication of genetic resources.

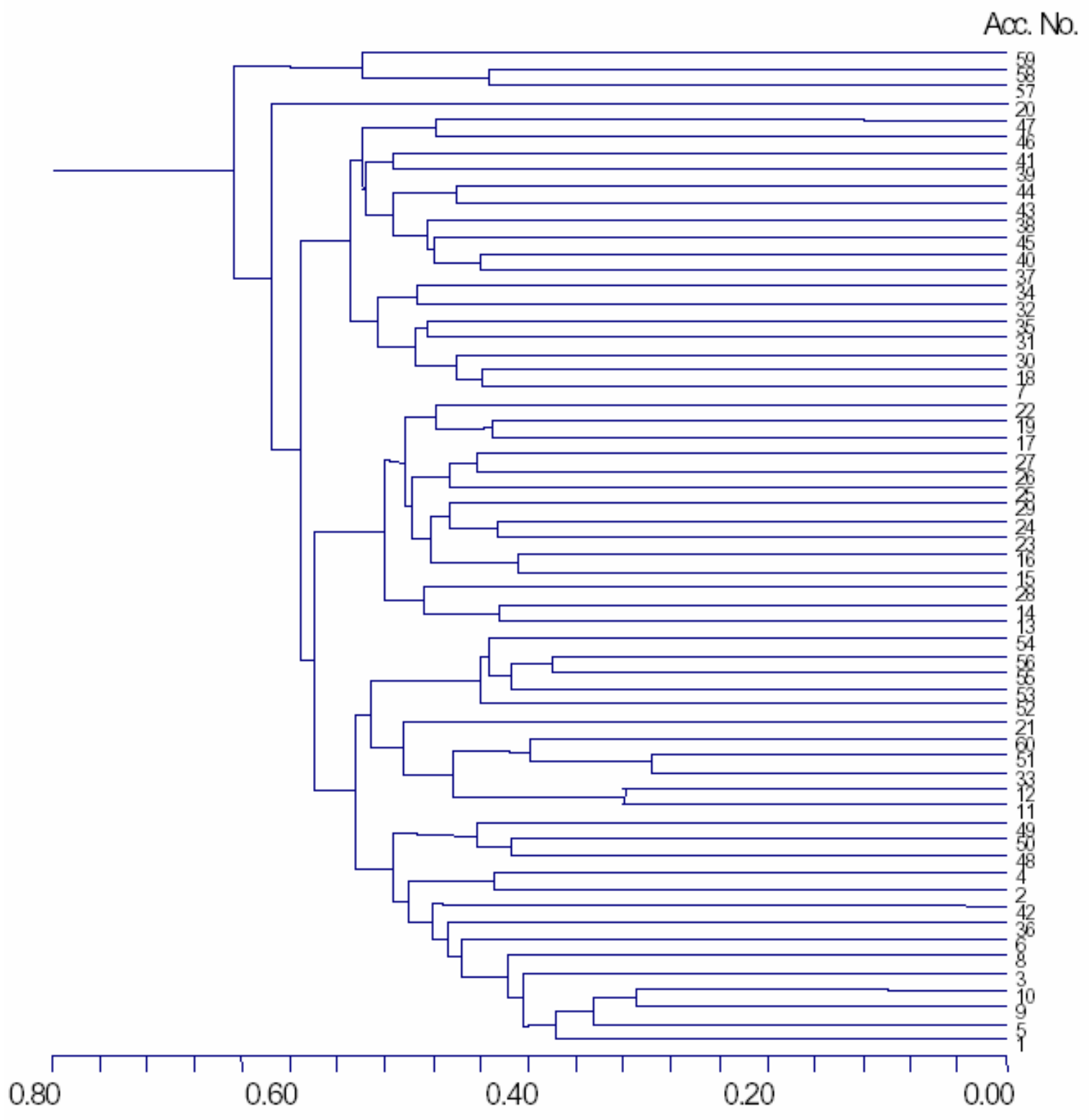

Dissimilarity

Fig. 1. Dendrogram indicating clusters of 60 accessions of linseed based on AFLP data, using UPGMAclustering method. 
Table 3. Cluster distribution of the 60 linseed accessions and their polymorphic and monomorphic rates based on the AFLP analysis, 2002.

\begin{tabular}{|c|c|c|c|c|}
\hline Cluster & $\begin{array}{l}\text { No. of } \\
\text { acc. }\end{array}$ & $\begin{array}{l}\text { Polymorphic } \\
(\%)\end{array}$ & $\begin{array}{l}\text { Monomorphic } \\
(\%)\end{array}$ & $\begin{array}{l}\text { Accession numbers and their collection areas, } \\
\text { as shown in the parenthesis }\end{array}$ \\
\hline I & 2 & 2.04 & 0.44 & 57, 58 (Saskatoon/ Canada) \\
\hline II & 5 & 1.41 & 0.22 & $52,53,54,55$ (Eth), 56 (USA) \\
\hline III & 2 & 2.29 & 0.11 & $47,46\left(\mathrm{G}^{-N W^{*}}\right)$ \\
\hline $\mathrm{V}$ & 3 & 1.80 & 0.47 & 13, 28 (Gr-NW), 14 (GG-SW) \\
\hline $\mathrm{V}$ & 2 & 1.73 & 0.16 & 32 (G-NW), 34 (S-C) \\
\hline VI & 5 & 1.97 & 0.25 & 7 (GNW), 18, 35 (S-C), 30 (Europe), 31 (Gr-NW) \\
\hline VII & 11 & 1.82 & 0.30 & $\begin{array}{l}15 \text { (G-NW), 16, } 17 \text { (H-E), 19, 22, } 23 \text { (S-C), } 24 \text { (S-S), } 25 \text { (T-N), } 26 \text { (W- } \\
\text { W), } 27(\mathrm{~W}-\mathrm{N}), 29 \text { (Gr-NW) }\end{array}$ \\
\hline VIII & 6 & 0.83 & 0.06 & 11 (B-S), 12 (W-W), 21, 33, 51 (S-C), 60 (Canada) \\
\hline IX & 14 & 1.43 & 0.32 & $\begin{array}{l}1 \text { (S-C), 2, } 8 \text { (S-S), } 3 \text { (K-SW), } 4 \text { (Gr-NW), } 5 \text { (H-E), } 6 \text { (W-N), } 9 \text { (Eritrea), } \\
10 \text { (A-S), } 36 \text { (S-C), } 42 \text { (B-S), 48, 49, 50, (Eth) }\end{array}$ \\
\hline$X$ & 2 & 2.04 & 0.22 & $39(\mathrm{~T}-\mathrm{N}), 41(\mathrm{I}-\mathrm{W})$ \\
\hline XI & 6 & 2.26 & 0.24 & 37 (W-N), 38 (I-W), 40 (S-C), 43 (T-N), 44 (Gr-NW), 45 (GG-W) \\
\hline XII & 1 & 1.29 & 0.40 & 20 (Europe) \\
\hline XIII & 1 & 2.90 & 0.11 & 59 (Canada) \\
\hline
\end{tabular}

* G-NW = Gojam-North West; Gr-NW = Gonder-North West; GG-SW = Gamo-Gofa-South West; S-C = Shewa-Centre; H-E = Hararge-East; I-W = Ilubabor-West; T-N = Tigray-North; B-S = Bale-South; Sidamo-South; Arsi-South; K-SW = Kefa-South West; $\mathrm{W}-\mathrm{N}=$ Welo-North; W-W = Welega - West; A-SE = Arsi South-East, parts of Ethiopia; Eth = Ethiopia, specific location could not be traced.

The overall genetic distance of all pairs of combinations varied from 0.29 to 0.71 (Fig. 2). The highest genetic distance was found between accession numbers 22 and 57. Similar genetic distances were also recorded for five pairs of accessions ( 25 and 57, 20 and 45, 23 and 59, 37 and 57 , and 45 and 57). The first pair of accession (22 and 57) that showed the highest diversity estimates (0.71) was obtained from local and exotic sources (Table 1). Accession no. 22 was collected from Ambo/ Ethiopia, while 57 was introduced from Canada in 1990 (Adugna Wakjira, 2000). Similarly, the next highest diversity estimate was observed between the same exotic genotype and another locally collected accession (No. 25) collected from northern Ethiopia. The same was true with the third divergent pair (No. 20 and 45), indicating the presence of immense genetic diversity between the Ethiopian linseed germplasm and the exotic ones, specifically those from Canada. This wide range of genetic distance shows the possibilities of creating greater genetic variability using these accessions in the crossing programs to meet various needs of linseed growers in the country. For example, early maturing and drought resistant varieties are preferred in the northern parts of Ethiopia; while medium to late maturing and parasitic weed (Cuscusta epilinum) and wilt (Fusarium oxysporium) resistant types are required in the central, northwest and southern parts of the country. Both pests have been the major production constraints in Ethiopia (Adugna Wakjira, 2000) and future research should focus on mapping and cloning of the resistant genes for them. More than $50 \%$ of the pairs of accessions displayed greater genetic diversity values than the mean value of 0.57 . There was also highly significant $(\mathrm{P}<0.001)$ difference between the pairs of accessions for these values. Nevertheless, accession pairs, like 9 and 10, and 11 and 12 exhibited one of the smallest genetic distances, indicating their genetic similarity. All of them were collected from different regions of Ethiopia except no. 9, which was acquired from Eritrea. In general, the relationship between genetic distance and geographic areas was large and positive between the Ethiopian collections and the introduced materials. 


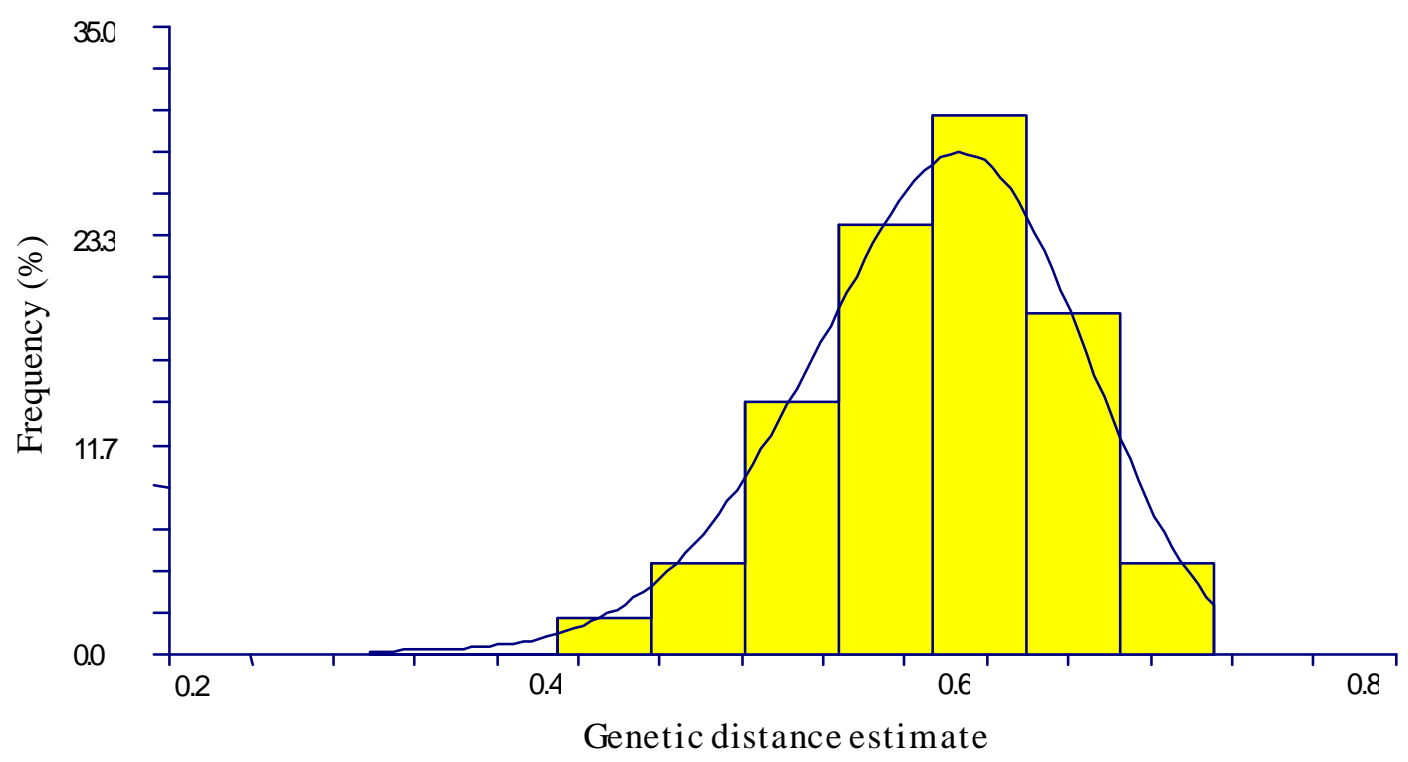

Fig. 2. Histogram depicting frequency distribution of genetic distances for all possible pairs of linseed accessions.

All the four commercial varieties (No. 10, 20, 30 and 40) included in this analysis were distinctly identified using AFLP markers in contrast to their phenotypic resemblance (Adugna Wakjira and Labuschagne, 2004). For example, No. 20 shared greater dissimilarity with other accessions and hence was not clustered with any group but unequivocally clustered away from the rest of accessions, showing its clear divergence. Similarly, no. 10, 30 and 40 were grouped in different clusters, indicating their distinct differences. These results indicate that AFLP analysis was effective to identify the accessions of linseed individually. Guthridge et al. (2001) and Lombard et al. (2002) have recently concluded that AFLP markers are effective in discriminating close-bred cultivars of perennial ryegrass and rapeseed inbred lines, respectively. Barret and Kidwell (1998) also concluded the pronounced efficiency of AFLP in diversity assessment of wheat cultivars.

To conclude, AFLP markers showed a reasonable level (i.e., up to $2.90 \%$ ) of DNA polymorphism among the analysed accessions of linseed. AFLPbased genetic distance estimates also revealed higher levels of genetic diversity among the accessions. Cluster analysis was useful to display the grouping patterns and relationships of individual accessions. This genetic information will contribute to linseed improvement through diverse parental selections and by providing a predictive measure of important parameters, such as genetic variance and heterosis for future variety development programs in Ethiopia. It is also vital for efficient management of germplasm.

\section{ACKNOWLEDGEMENTS}

The financial support of the Agricultural Research and Training Project of EARO for the study of the senior author is gratefully acknowledged.

\section{REFERENCES}

1. Adugna Wakjira (2000). Assessment of tissue culture derived regenerants of linseed (Linum usitatissimum L.) in Ethiopia. M. Sc. Thesis, Department of Plant Breeding, Faculty of Agric. Univ. of the Free State, Bloemfontein, South Africa. 
2. Adugna Wakjira and Labuschagne, M.T. (2002). Genotype-environment interactions and phenotypic stability analyses of linseed in Ethiopia. Plant Breeding 121(1):66-71.

3. Adugna Wakjira and Labuschagne, M.T. (2003a). Parametric and nonparametric measures of phenotypic stability in linseed (Linum usitatissimum L.). Euphytica 129:211-218.

4. Adugna Wakjira and Labuschagne, M.T. (2003b). Association of linseed characters and its variability in different environments. J. Agric. Sci. (Cambridge) 140:297-304.

5. Adugna Wakjira and Labuschagne, M.T. (2004). Diversity analysis in Ethiopian and some exotic collections of linseed. South African J. Plant Soil 21(1):53-58.

6. Altaf Khan, M., Myers, G.O. and Stewart, J.M. (2002). Molecular markers, genomics and cotton improvement. In: Crop Improvement Challenges in the Twenty First Century, pp. 253-284, (Kang, M.S., ed.) Food Products Press ${ }^{\circledR}$, New York.

7. Barret, B.A. and Kidwell, K.K. (1998). AFLP-based genetic diversity assessment among wheat cultivars from the Pacific Northwest. Crop Sci. 38:1261-1271.

8. CSA (2001). Central Statistical Authority. Estimates of area, production and yield of temporary crops for private peasant holdings for main seasons, 2001/2002. CSA, Addis Ababa, Ethiopia.

9. Edwards, K., Johnstone, C. and Thompson, C. (1991). A simple and rapid method for the preparation of plant genomic DNA for PCR analysis. Nucl. Acids Res. 19:1349.

10. Guthridge, K.M., Dupal, M.P., Kolliker, R., Jones, E.S., Smith, K.F. and Forster, J.W. (2001). AFLP analysis of genetic diversity within and between populations of perennial ryegrass (Lolium perenne L.). Euphytica 122:191-201.

11. Hausner, G., Rashid, K.Y. and Kenaschuk, E.O. (1998). The development of co-dominant PCR/RFLP based markers for flax rust resistance alleles at L locus. Genome. 42:1-8.
12. Hintze, J.L. (1998). NCSS 2000 Statistical System for Windows. Number Cruncher Statistical Systems. Kaysville, Utah.

13. Kumar, L.S. (1999). DNA markers in plant improvement: An overview. Biotechnology Advances 17:143-182.

14. Lombard, V., Tireau, B., Blouet, F., Zhang, D. and Baril, C.P. (2002). Usefulness of AFLP markers to estimate varietal homogeneity of rapeseed inbred line varieties in the context of plant registration and protection. Euphytica 125:121127.

15. Luhs, W. and Friedt, W. (1994). Major Oil Crops. In: Designer Oilseed Crops, pp. 5-71, (Murphy, D.J., ed.) VCH Press Ltd, Weinheim.

16. Majer, D., Mithen, R., Lewis, B.G., Vos, P. and Oliver, R.P. (1996). The use of AFLP fingerprinting for the detection of genetic variation in fungi. Mycological Res. 100:1107-1111.

17. Mansby, E., Diaz, O. and von Bothmer, R. (2000). Preliminary study of genetic diversity in Swedish flax (Linum usitatissimum). Genetic Resource and Crop Evol. 47:417-424.

18. Morris, D.H. (2004). Flax-A Health and Nutrition Primer. http://www.flaxcouncil.ca

19. Payne, T.J. (2000). Promoting better health with flaxseed in bread. Cereal Foods World 45:102104.

20. PE (2002). Perkin-Elmer. Applied Biosystems. http://www.perkin.elmmer.com

21. Powell, W., Morgante, M., Andre, C., Hanafey, M.M., Vogel, J., Tingey, S. and Rafalski, A. (1996). The comparison of RFLP, RAPD, AFLP, and SSR (microsatellite) markers for germplasm analysis. Mol. Breeding 2:225-238.

22. Roldan-Ruiz, I., van Eeuwijk, F.A., Gilliland, T.J., Dubreuil, P., Dillmann, C, Lallemand, J., De Lose, M. and Baril, C.P. (2001). A comparative study of molecular and morphological methods of describing relationships between perennial ryegrass (Lolium perenne L.) varieties. Theor. Appl. Genet. 103:1138-1150. 
23. Spielmeyer, W., Green, A.G., Bittisnich, D., Mendham, N. and Lagudah, E.S. (1998). Identification of quantitative trait loci contributing to Fusarium wilt resistance on AFLP linkage map of flax. Theor. Appl. Genet. 97:633-641.

24. UPOV (1991). International convention for the protection of new varieties of plant. http://www.upov.int
25. Vos, P.H., Bleeker, R. Rijans, M., van Der Lee, M, Hornes, M., Frijters, A., Pot, J.P., Kuiper, M. and Zabeau, M. (1995). AFLP: A new technique for DNA fingerprinting. Nucl. Acids Res. 23:44074414 .

26. Zabeau, M. and Vos, P. (1993). Selective restriction fragment amplification: A general method for DNA fingerprinting. European Patent Application Number: 92402629.7, Publication No. EP0534 858A1. 